\title{
Phlogopite-chlorite reaction mechanisms and physical conditions during retrograde reactions in the Marble Formation, Franklin, New Jersey
}

\author{
Yu-Chyi Yau, Lawrence M. Anovitz, Eric J. Essene, and Donald R. Peacor \\ Department of Geological Sciences, The University of Michigan, Ann Arbor, Michigan 48109, USA
}

\begin{abstract}
A retrograde assemblage in a specimen from the Franklin Marble Formation containing an unusual occurrence of three micas has been studied. Microprobe analyses of the margarite, muscovite and phlogopite reveal significant sodium and fluorine but otherwise show little mutual solid solution. The conditions that prevailed during the retrogression estimated from phase equilibria are $T=370$ $450^{\circ} \mathrm{C}$ and $X_{\mathrm{CO}_{2}}=0.03-0.3$ at an assumed pressure of $2 \mathrm{~kb}$.

Examination of the phlogopite by TEM revealed replacement of phlogopite by chlorite. The chlorite occurred as small packets of layers interlayered with phlogopite. AEM analyses revealed that the chlorite composition approximates that of clinochlore. Transformations from a single phlogopite layer to one chlorite layer (a 1:1 reaction) and also from two phlogopite layers to one chlorite layer (a 2:1 reaction) have been observed. Both reactions result in a large volume change causing local strain at transition fronts. An apparently strain-free, volume-preserving transformation of 14 phlogopite layers terminating against 10 chlorite layers was observed which indicates that pervasive replacement may occur through a combination of both reactions. Topological and site occupancy changes during the transformation suggest that the reaction involves not only gain and loss of layer units, but also considerable local rupturing and reformation of bonds, concomitant with ion diffusion and interchange. Dislocations (layer terminations) at the transition front imply the existence of pathways for the fluid flow and ion transport required for mass balance.
\end{abstract}

\section{Introduction}

Determination of the microstructural relations and chemical distributions at the interface between phases associated with alteration processes is essential for understanding the detailed reaction mechanisms involved in the replacement processes. Mechanisms and pathways for ion or atom cluster transport have yet to be established, although the nature of alteration interfaces should provide data on such problems. The manner in which the primary structure is modified has received considerable attention from many mineralogists (Berner and Holdren 1977; Page and Wenk 1979;

\footnotetext{
* Contribution No. 397 from the Mineralogical Laboratory, Department of Geological Sciences, The University of Michigan, Ann Arbor, Michigan, USA
}

Veblen and Buseck 1981; Veblen 1983; Cressey et al. 1982). In attempting to understand reaction mechanisms, numerous workers have focused on transformations involving phases with common structural features such as biotitechlorite (e.g. Ferry 1979; Olives et al. 1983; Veblen and Ferry 1983) and pyroxene-amphibole (e.g. Nakajima and Ribbe 1980; Isaacs et al. 1981).

Because the scale of both mineralogical and chemical heterogeneity may be beyond the resolution of conventional analytical tools, transmission electron microscopy (TEM) has recently been used for such studies (e.g. Veblen and Buseck 1980; Veblen and Ferry 1983). On the scale observable with TEM (less than $4 \AA$ ), the reaction topology can be examined in great detail; for example, transitions from one phyllosilicate to another along individual layers have commonly been observed (Page 1980; Lee et al. 1983). In this paper we describe TEM observations of phlogopite altering to chlorite in a specimen from the Franklin Marble Formation, Franklin, New Jersey. The mineral assemblage present in our sample allows an estimate of the conditions of the retrogression to be made. Textural relations between parent and product structures observed on the scale of a few tens of Angstroms provide new insights into the reaction mechanisms involved in the replacement processes, and imply the existence of pathways for fluid flow and ion transport.

\section{Sample characterization and experimental procedure}

The sample examined in this study is from the Franklin Marble Formation, Farber Quarry, Franklin, New Jersey. This formation is part of a series of Precambrian sedimentary rocks metamorphosed to the granulite facies (Baker and Buddington 1970). The samples was originally provided by Dr. Pete Dunn whose identification of margarite led to our study. The upper stability limit of the assemblage margarite and quartz is constrained to the lower amphibolite facies (Storre and Nitsch 1971), suggesting that this rock has undergone retrograde reequilibration.

Initial examination suggests that the rock was originally a calcsilicate composed of feldspars and/or scapolites, but it has undergone extensive sericitization obscuring the parent assemblage. Contained within the altered matrix are undeformed augen of phlogopites associated with other minerals. Optical examination of polished thin sections showed that phlogopite exhibits textural evidence of replacement. Fine-grained sericite, calcite, dolomite, and occasionally margarite are seen along phlogopite cleavages. The rock consists of margarite, phlogopite, dolomite, calcite, quartz, rutile and sphene with fine-grained sericite replacing feldspar or scapolite. No chlorite was detected under the microscope or through X-ray powder diffraction. However, an X-ray powder 
Table 1. Representative electron microprobe analyses

\begin{tabular}{|c|c|c|c|c|}
\hline Phase & Margarite & Phlogopite & Muscovite & Sphene \\
\hline $\mathrm{SiO}_{2}$ & 29.04 & 40.49 & 42.80 & 31.80 \\
\hline $\mathrm{TiO}_{2}$ & 0.04 & 0.18 & $<0.03$ & 26.28 \\
\hline $\mathrm{Al}_{2} \mathrm{O}_{3}$ & 51.20 & 12.04 & 38.95 & 6.74 \\
\hline $\mathrm{FeO}^{*}$ & 0.04 & 1.61 & 0.10 & $<0.03$ \\
\hline $\mathrm{MnO}$ & $<0.03$ & 0.04 & 0.05 & 0.09 \\
\hline $\mathrm{MgO}$ & 0.15 & 26.35 & 0.80 & 0.14 \\
\hline $\mathrm{CaO}$ & 12.14 & $<0.03$ & 0.33 & 33.39 \\
\hline $\mathrm{Na}_{2} \mathrm{O}$ & 0.82 & 0.55 & 0.41 & - \\
\hline $\mathrm{K}_{2} \mathrm{O}$ & 0.31 & 10.33 & 10.28 & - \\
\hline $\mathrm{BaO}$ & $<0.03$ & 0.27 & 0.04 & - \\
\hline $\mathrm{H}_{2} \mathrm{O}^{+}$ & 4.43 & 0.56 & 4.81 & 0.70 \\
\hline $\mathrm{F}$ & 1.03 & 7.13 & 0.20 & 1.74 \\
\hline $\mathrm{Cl}$ & 0.06 & 0.13 & $<0.03$ & $<0.03$ \\
\hline 'Total wt. \% & 98.81 & 96.66 & 98.70 & 100.14 \\
\hline $\mathrm{Si}$ & 3.89 & 5.94 & 5.70 & 3.93 \\
\hline $\mathrm{Al}^{\mathrm{IV}}$ & 4.12 & 2.06 & 2.30 & 0.07 \\
\hline $\mathrm{Al}^{\mathrm{VI}}$ & 3.96 & 0.02 & 3.82 & 0.90 \\
\hline $\mathrm{Ti}$ & $<0.01$ & 0.02 & $<0.01$ & 2.95 \\
\hline $\mathrm{Fe}^{2+*}$ & 0.01 & 0.20 & 0.01 & $<0.01$ \\
\hline $\mathrm{Mn}$ & $<0.01$ & $<0.01$ & 0.01 & 0.01 \\
\hline $\mathrm{Mg}$ & 0.03 & 5.76 & 0.16 & 0.03 \\
\hline $\mathrm{Ca}$ & 1.74 & $<0.01$ & 0.05 & 4.12 \\
\hline $\mathrm{Na}$ & 0.21 & 0.16 & 0.11 & - \\
\hline $\mathrm{K}$ & 0.05 & 1.93 & 1.75 & - \\
\hline $\mathrm{Ba}$ & $<0.01$ & 0.02 & $<0.01$ & - \\
\hline$F$ & 0.44 & 3.31 & 0.08 & 0.67 \\
\hline $\mathrm{Cl}$ & 0.01 & 0.03 & $<0.01$ & $<0.01$ \\
\hline $\mathrm{O}^{* *}$ & $<0.01$ & 0.12 & $<0.01$ & - \\
\hline $\mathrm{O}^{* * *}$ & 19.60 & 20.00 & 19.64 & 18.75 \\
\hline $\mathrm{OH}^{* *}$ & 3.55 & 0.54 & 3.92 & - \\
\hline $\mathrm{OH}^{* * *}$ & 0.40 & $<0.01$ & 0.36 & 0.58 \\
\hline
\end{tabular}

Normalized to $\Sigma$ cations-K, $\mathrm{Na}, \mathrm{Ba}, \mathrm{Ca}=12$ for $\mathrm{Mrg}$ and $\mathrm{Musc}$ or 14 for Phl. Sphene normalized to 12 total cations. 'oxide totals corrected for fluorine and chlorine oxygen equivalents; + calculated; * all $\mathrm{Fe}$ calculated as ferrous iron; ** in $\mathrm{OH}$ site; *** in $\mathrm{O}$ site

diffraction pattern obtained from hand-picked phlogopite grains reveals the presence of a small amount of a highly hydrated layer silicate with $\mathrm{d}(001)=18.8 \AA$.

Chemical analyses were obtained using the University of Michigan ARL-EMX electron microprobe analyzer with an energydispersive spectrometer and wavelength-dispersive PET, LiF, and TAP crystal spectrometers. Well analyzed natural minerals were used as standards for quantitative analysis. Data were corrected for atomic number, fluorescence, absorption, continuous back- ground and machine drift effects with the Fortran program EMPADR VII (Rucklidge and Gasparrini 1969). For TEM studies, samples containing phlogopite interlayered with margarite were removed from thin sections and ion-thinned using an argon beam to obtain electron transparent thin edges. The University of Michigan JEM-100CX transmission electron microscope operated at $100 \mathrm{kV}$ with a side-entry stage was used for observation of the sample. The specimen was tilted to bring (001) planes parallel to the electron beam. Electron diffraction patterns of selected areas were obtained, followed by recording of (001) lattice fringe images. Qualitative analyses were performed using an energy dispersive detector attached to the TEM, with special attention being given to possible variations in composition across phlogopite-chlorite interfaces.

\section{Analytical results}

Microprobe analyses of several of the minerals in this sample are listed in Table 1 . The margarite analyses reveal substitution of $\mathrm{F}$ and $\mathrm{Cl}$ for $\mathrm{OH}$, and $\mathrm{Na}$ for $\mathrm{Ca}$. Because the exchange of $\mathrm{Na}$ for $\mathrm{Ca}$ is not balanced by exchange of $\mathrm{Si}$ for $\mathrm{Al}$, the charge balance may be maintained by exchange of $\mathrm{OH}$ for $\mathrm{O}$ or by small trioctahedral substitutions in the octahedral layer. Without accurate water analyses the relative importance of these two mechanisms cannot be evaluated.

The phlogopites are very fluorine-rich (approximately 85\% F-phlogopite) and also contain small chlorine- and oxy-components. This fluorine level exceeds all but a very few of those in reported fluorphlogopites (Valley et al. 1982). The excess cation total in the potassium site may be an artifact of analytical error. Despite its occurrence in the same rock as margarite, the phlogopite shows no calcium solid solution towards either dioctahedral margarite or trioctahedral clintonite. The muscovites in this sample are generally fine-grained, but a few grains were large enough to analyze. The analysis shows about $5 \%$ replacement of $\mathrm{K}$ by $\mathrm{Ca}$, but this may be due to submicroscopic interlayers of margarite. The sphene shows $25 \%$ substitution of $\mathrm{Al}$ for Ti charge-balanced by $\mathrm{OH}$ and $\mathrm{F}$ for $\mathrm{O}$. Calcite and dolomite analyses yield the compositions $\left(\mathrm{Ca}_{0.97}\right.$ $\left.\mathrm{Mg}_{0.02} \mathrm{Fe}_{0.01}\right) \mathrm{CO}_{3}$ and $\left(\mathrm{Ca}_{0.49} \mathrm{Mg}_{0.48} \mathrm{Fe}_{0.02} \mathrm{Mn}_{0.01}\right) \mathrm{CO}_{3}$ respectively, which fall very close to the calcite-dolomite join.

\section{Phase equilibria}

The assemblage margarite - phlogopite - calcite - dolomite - quartz - rutile - graphite - sphene allows constraints to be placed on the $P-T-X$ conditions if the assemblage

Table 2. Thermodynamic data used in this study

\begin{tabular}{|c|c|c|c|c|c|c|c|}
\hline Phase & $V_{298}^{o}$ & $S_{298}^{0}$ & $A$ & $B$ & $C$ & $D$ & Ref. \\
\hline Phlogopite (Phl) & 149.66 & 75.50 & 92.8590088 & 32.2079926 & 4.7075014 & -545.700195 & 4 \\
\hline Margarite (Mrg) & 133.77 & 63.02 & 92.5693820 & 32.5486760 & 10.0167200 & -548.59619 & 3 \\
\hline Anorthite (An) & 100.79 & 47.63 & 63.0265960 & 15.0211697 & 7.5215101 & -372.056152 & 3 \\
\hline Andalusite (And) & 51.53 & 22.28 & 42.2777560 & 5.4315310 & 6.8636541 & -250.20799 & 1 \\
\hline Tremolite (Tr) & 272.92 & 131.19 & 174.5645040 & 78.1535602 & 16.6607526 & -1036.81644 & 1 \\
\hline Quartz $(\mathrm{Qz})$ & 22.69 & 9.91 & 17.5642670 & 0.1876184 & 3.6750740 & -104.240801 & 1 \\
\hline Calcite (Cc) & 36.93 & 21.93 & 24.5972250 & 5.6011761 & 2.9184167 & -145.0900 & 1 \\
\hline Sphene (Sph) & 55.65 & 30.88 & 42.2956988 & 5.6643275 & 4.8232497 & -248.0500 & 1 \\
\hline Rutile (Ru) & 18.82 & 12.02 & 15.0225742 & 2.7160936 & 1.1936939 & -87.74525 & 1,2 \\
\hline
\end{tabular}

$S_{T}^{\mathrm{o}}-S_{298}^{\mathrm{o}}\left(\mathrm{cal} / \mathrm{mole}^{\circ} \mathrm{K}\right)=A \cdot 1 \mathrm{n} T+10^{-3} B \cdot T+10^{5} \mathrm{C} \cdot T^{-2}+D ; V_{298}^{\mathrm{o}}(\mathrm{cc} / \mathrm{mol})$

(1) Robie et al. (1978); (2) JANAF (1975); (3) Robinson et al. (1983); (4) Robie and Hemingway (1984) 


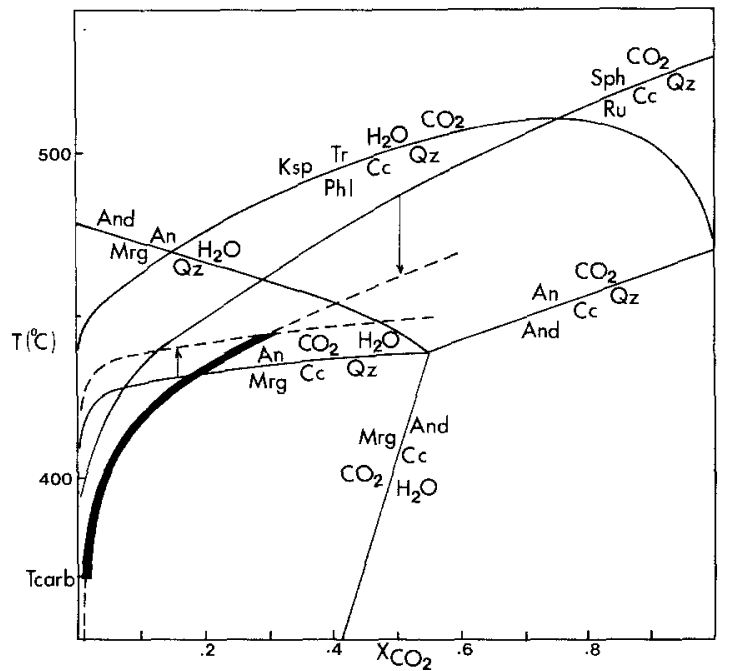

Fig. 1. T-X phase equilibria calculated for end member compositions (solid curves) and corrected for solid solutions (dash curves). $T_{\text {earb }}\left(370^{\circ} \mathrm{C}\right)$ calculated from calcite-dolomite thermometry. The darkened line represents the conditions of our sample containing phl, mrg, ru, sph, cc, qz. Reaction (1) was calculated from the reversal of $2 \mathrm{~kb}, 520^{\circ} \mathrm{C}, X_{\mathrm{CO}}=0.78$ (Jacobs and Kerrick 1981), reaction (3) from $6 \mathrm{~kb}, 620^{\circ} \mathrm{C}, X_{\mathrm{CO}_{2}}=0.56$ (Hoschek 1973), and $\mathrm{An}+\mathrm{CO}_{2}=\mathrm{Cc}+\mathrm{Qz}+$ And from $2 \mathrm{~kb}, 450^{\circ} \mathrm{C}, X_{\mathrm{CO}_{2}}=0.69$ (Jacobs and Kerrick 1981)

was at equilibrium. The conditions of the event during which these phases equilibrated must lie along the reaction:

rutile + calcite + quartz $=$ sphene $+\mathrm{CO}_{2}$

(Jacobs and Kerrick 1981), and below the reactions:

margarite + calcite + quartz

$=$ anorthite $+\mathrm{CO}_{2}+\mathrm{H}_{2} \mathrm{O}$

(Storre and Nitsch 1974), and:

phlogopite + calcite + quartz

$=\mathrm{K}$-feldspar + tremolite $+\mathrm{CO}_{2}+\mathrm{H}_{2} \mathrm{O}$

(Hoschek 1973). These equilibria constrain both the maximum temperature and $X_{\mathrm{CO}_{2}}$ if the pressure is known. In order to quantify these constraints, phase equilibria are calculated using thermodynamic data in Table 2 . The nonideal mixing properties of $\mathrm{H}_{2} \mathrm{O}$ and $\mathrm{CO}_{2}$ were calculated from the model of Kerrick and Jacobs (1981). All calculations were performed using the program EQUILI (Wall and Essene unpbd.) which is similar to that of Slaughter et al. (1976). The intersection of reactions (1) and (2) limits the maximum equilibration temperature (Fig. 1). Equilibrium conditions must lie along reaction (3) below this intersect point, which therefore also represents the maximum value of $X_{\mathrm{CO}_{2}}$ in the fluid.

Reactions (1) and (2) have been corrected for solid-solution effects in order to apply the end-member phase equilibria to the Franklin sample. Calcite activities were calculated using the data of Anovitz and Essene (1984). The activities of margarite and sphene were calculated as

$a_{\mathrm{Mg}}=\left(X_{\mathrm{Ca}}\right)\left(X_{\mathrm{Al}}\right)^{2}\left(X_{\mathrm{OH}}\right)^{4}$

$a_{\mathrm{Sph}}=\left(X_{\mathrm{Ca}}\right)\left(X_{\mathrm{Ti}}\right)\left(X_{\mathrm{Si}}\right)$.

The corrected curves suggest a maximum temperature of $450^{\circ} \mathrm{C}$, and a maximum for $X_{\mathrm{CO}_{2}}=0.3$ at an assumed pressure of $2 \mathrm{~kb}$ (Fig. 1).
An equilibration temperature may also be calculated for the calcite/dolomite assemblage (Goldsmith and Newton 1969; Anovitz and Essene 1984). As no exsolution textures were observed in the calcite, it was not possible to ascertain whether peak conditions were recorded. The results obtained using the calibration of Anovitz and Essene (1984) give a temperature of $370^{\circ} \mathrm{C}$ and $X_{\mathrm{CO}_{2}}=0.03$, which agrees well with the conditions imposed by the equilibria discussed above.

\section{TEM and AEM results and interpretations}

\section{Stacking phenomena of phlogopite and margarite}

Under the optical microscope, margarite is seen to be interleaved with phlogopite, suggesting that interlayering features between dioctahedral and trioctahedral micas would be found at the TEM scale. Because the observed texture implies that margarite replaces phlogopite, the interface between these phases might show unusual structural and chemical relations. However, under TEM examination, phlogopite is always separated from margarite by calcite and/or dolomite and no interlayering relations between these two micas could be observed.

A lattice fringe image and an electron diffraction pattern of $(001)$ reflections was obtained from a region of fresh phlogopite. The $10 \AA$ spacing between lines in the image corresponds to the (001) interplanar spacing of a one-layer polytype of phlogopite (Fig. 2). Observations from four different phlogopite grains at various tilting angles relative to the electron beam and including many reflections in addition to 001 reflections showed only $10 \AA$ spacings, suggesting that only the single-layer phlogopite polytype is present. In addition, as the diffraction pattern shows no streaking in the [001] direction, there is no evidence for stacking disorder. This is consistent with X-ray studies of phlogopite from Franklin, New Jersey (Hazen and Burnham 1973).

Margarite commonly occurs as a 2-layer polytype (Takéuchi 1965; Bailey 1975). However, our TEM observations (Fig. 3) revealed individual 3-layer and 5-layer units irregularly mixed within the dominant 2-layer polytype. The $20 \AA$ spacing between fringes for the 2-layer polytype corresponds to the interplanar distance of a 2-layer polytype. This image was obtained using an aperture which included only 001 reflections. The attached electron diffraction pattern, which corresponds to the image area, shows diffuseness parallel to $c^{*}$, due to the existence of different units.

\section{Replacement of phlogopite by chlorite}

Chlorite was not observed at the resolution of the petrographic microscope. However, when ion-thinned samples were examined by TEM, $14 \AA$ chlorite layers were found within $10 \AA$ phlogopite layers near the regions where calcite, dolomite, and/or margarite are associated with the phlogopite. This association is shown in a low magnification bright-field TEM micrograph (Fig. 4), in which calcite occurs between phlogopite structural layers. Figure 5 is a higher magnification TEM image corresponding to the outlined rectangular region in Fig. 4. In this area, a transition zone of disordered, mixed-layers of phlogopite and chlorite separates packets of homogeneous chlorite and phlogopite. Chlorite layers are identified from the characteristic interplanar $14 \AA$ spacing in the lattice fringe images and the 

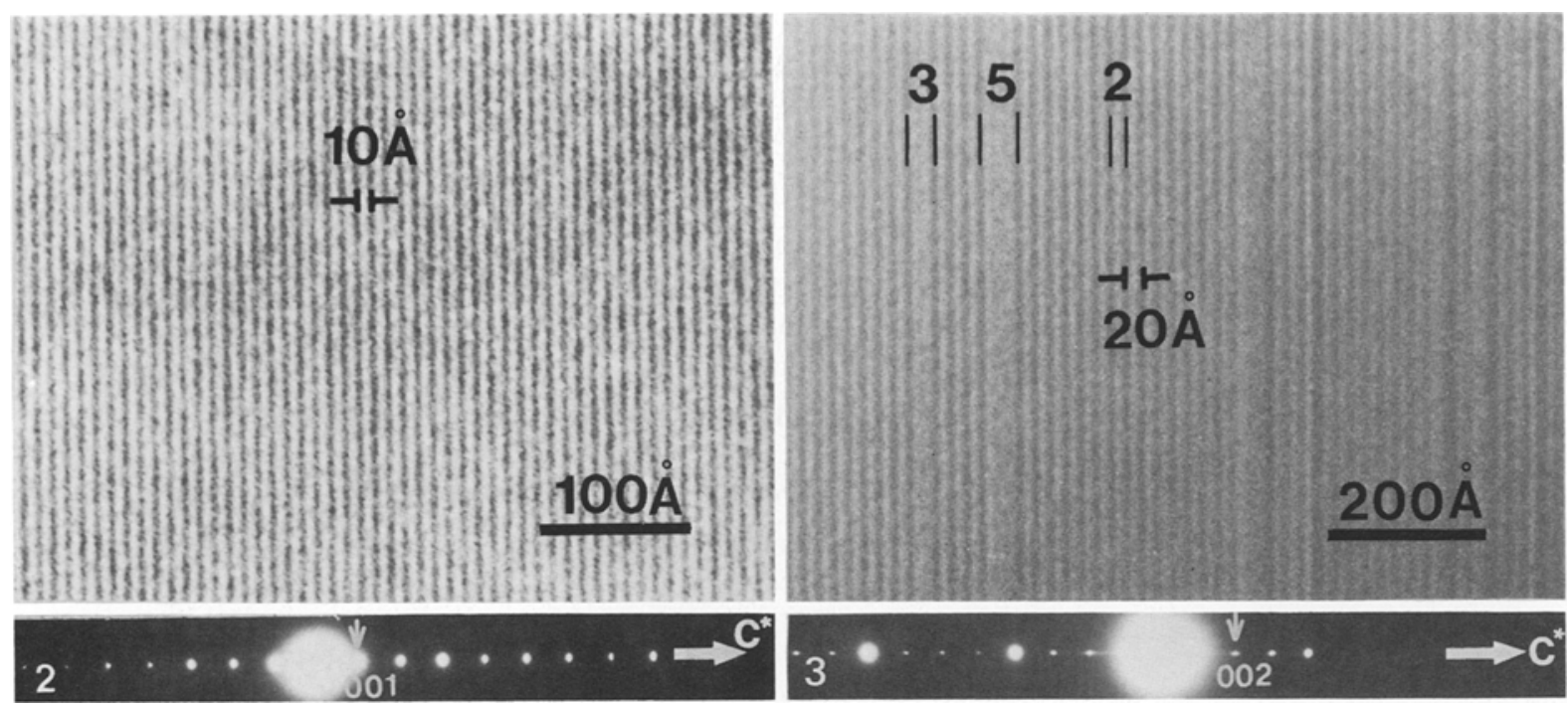

Fig. 2. Lattice fringe image and electron diffraction pattern of a phlogopite showing an ordered one-layer (10 $\AA$ ) stacking sequence

Fig. 3. Lattice fringe image and electron diffraction pattern of margarite consisting mostly of two-layer (20 $\mathrm{\AA})$ polytype interlayered with 3- and 5-layered units
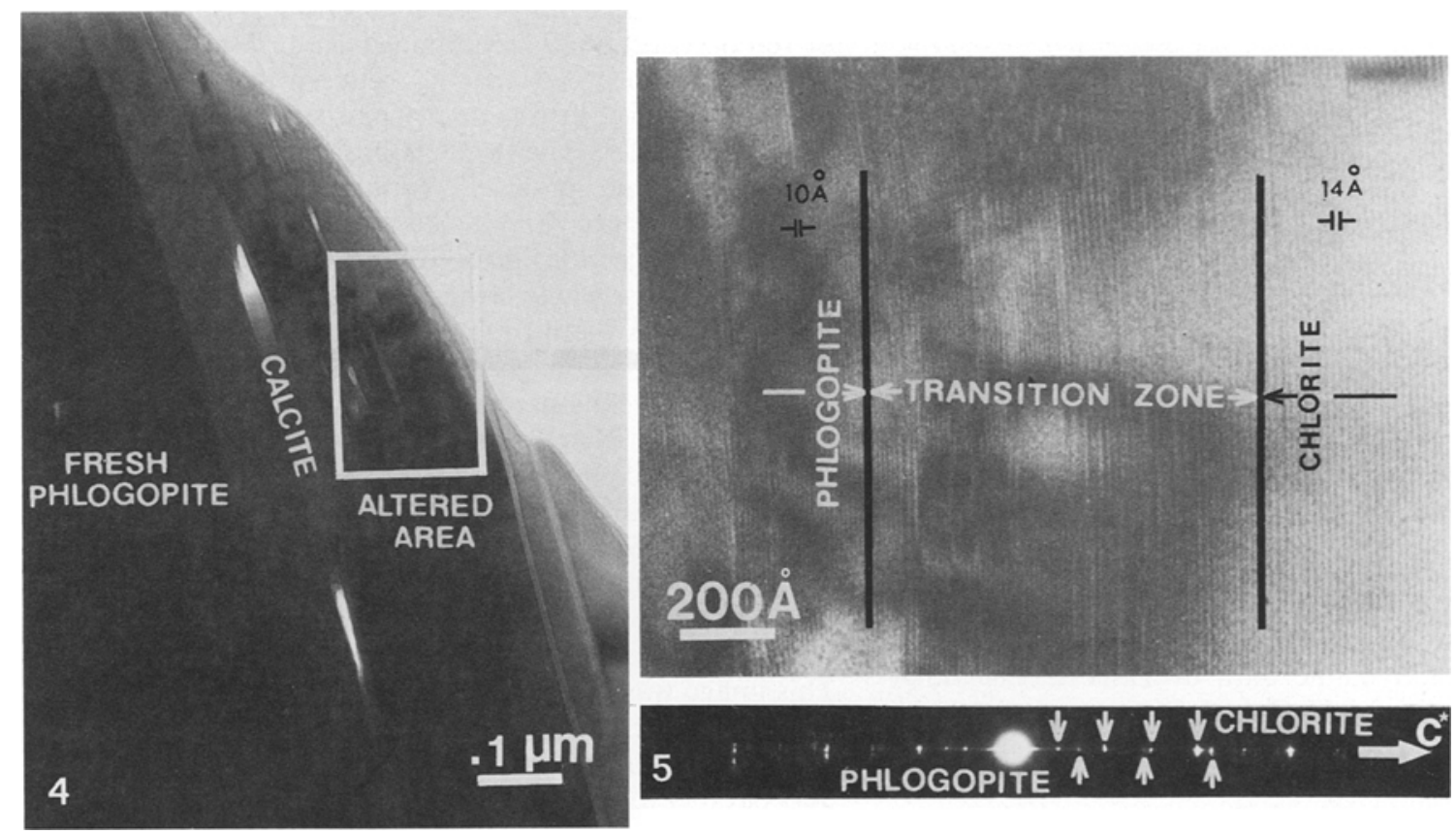

Fig. 4. Low magnification electron micrograph of fresh and altered phlogopite in association with calcite occurring along phlogopite structural layers

Fig. 5. Lattice fringe image and electron diffraction pattern of the rectangular region outlined in Fig. 4. Packages of homogeneous chlorite and phlogopite layers are separated by a chlorite-phlogopite mixed layering transition zone

corresponding electron diffraction patterns (inserts in Fig. 5). The streaking along $\mathrm{c}^{*}$ seen in the pattern results from the random interlayering of chlorite and phlogopite in the transition zone. An enlargement of this transition zone shows complex interlayering relations between phlogopite and chlorite (Fig. 6a). A local ordering involving interleaving of two phlogopite layers (2 P) with one chlorite layer (C) is shown. However, the distance over which the sequence occurs in this case is much too small to definitely constitute a meaningful repeat, and it is therefore of uncer- tain significance. Ordered 1:2 mixed-layered chlorite/mica has also been observed by Ahn and Peacor (personal communication).

Some of the phlogopite layer pairs terminate in a single chlorite layer (indicated by circles in Fig. 6a). This type of termination, also observed by Veblen and Ferry (1983), is shown more clearly in Figure 6b. In both figures, considerable strain contrast, edge dislocations and bending of the nearby layers (indicated by arrows) are found in association with the phlogopite-chlorite layer terminations. A second 

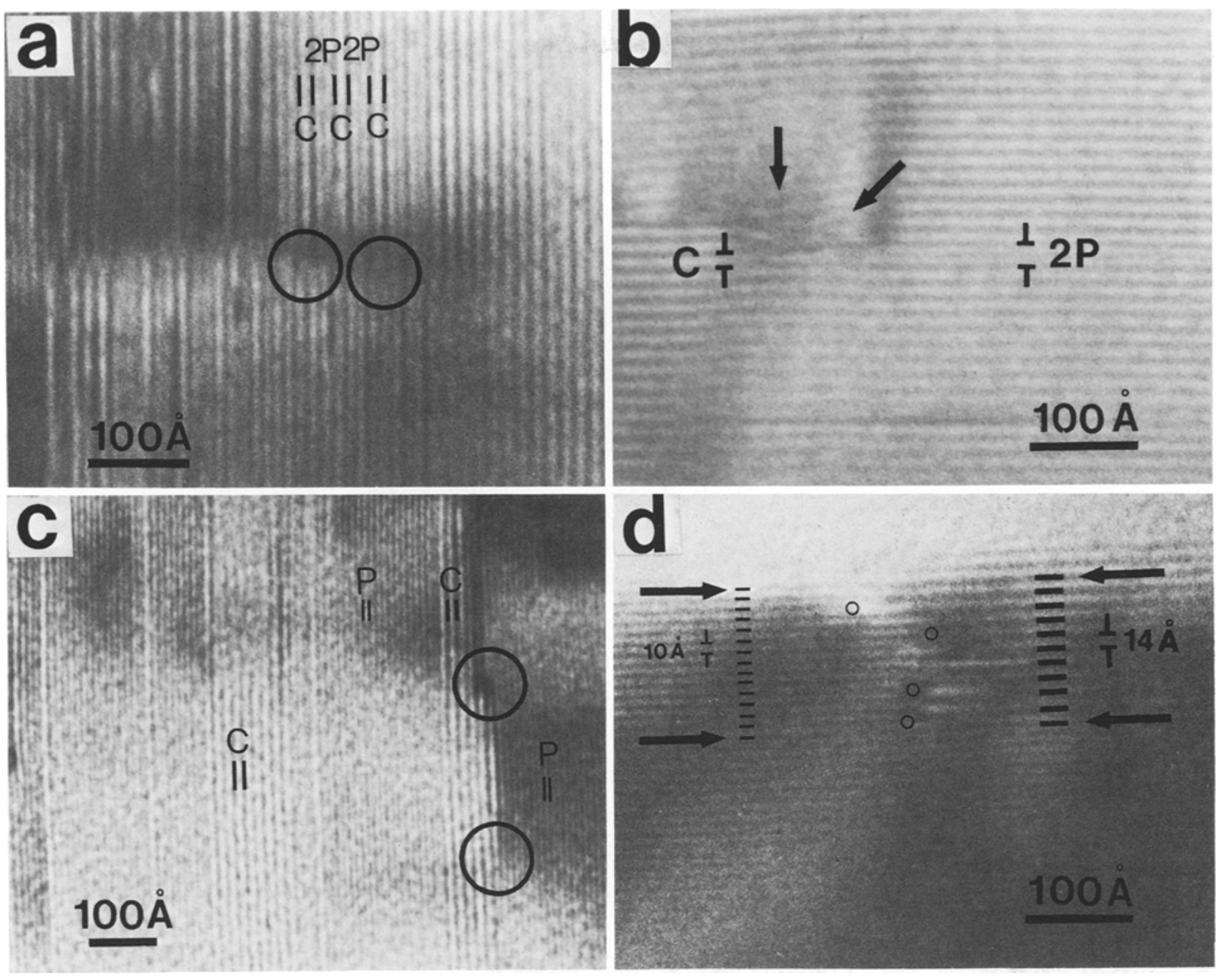

Fig. 6a-d. Lattice fringe images of phlogopite (P)-chlorite (C) interlayering relations: a An enlargement of the transition zone in Fig. 5 shows local ordering of $2 \mathrm{P}$ and $1 \mathrm{C}$. Transitions from $2 \mathrm{P}$ to $1 \mathrm{C}$ are shown in circles. $\mathbf{b} \mathrm{A}$ transition from $2 \mathrm{P}$ to $1 \mathrm{C}$. Arrows point out the associated bending and edge dislocation in the nearby layers. c Small packets of chlorite layers interlayered with phlogopite layers. Partial terminations from $1 \mathrm{C}$ to $1 \mathrm{P}$ are shown in circles. d An interlayering transformation from 14 phlogopite layers to 10 chlorite layers. Four TOT structural layers of phlogopite terminate at edge dislocations (shown as small circles)

area in this sample shows small packets of chlorite layers interlayered with phlogopite (Fig. 6c). A different type of termination, also observed by Veblen (1983) and Olives and Amouric (1984), in which a single phlogopite layer is converted to one chlorite layer is evident in this figure (indicated by circles). In all cases, however, the chlorite layers apparently occur coherently or semicoherently within packets of phlogopite layers. An unidentified phase with a very diffuse electron diffraction pattern was observed nearby. Its corresponding image shows wavy contrast but no lattice fringes. The lack of sharp diffraction maxima and welldefined lattice fringes may be due either to poor crystallinity or to damage caused by the electron beam. We suspect that this phase might correspond to the apparently highly hydrated phase identified by X-ray powder diffraction.

Perhaps one of the most significant observations of this study is illustrated in Figure 6d, where a packet of chlorite layers terminates against a packet of phlogopite layers. In this image, apparently straight 001 lattice fringes can be traced above and below the interface, indicating structural continuity in those layers. In the region between two such continuous layers, 14 phlogopite layers have been transformed into 10 chlorite layers with no apparent change in volume. At the interface, four phlogopite layers terminate as edge dislocations, and no obvious strain contrast is associated with the transformation. The significance of these observations is discussed below.

\section{Chemical analysis across the phlogopite-chlorite interface}

Chlorite could be observed only rarely at the level of TEM resolution and it appears even then only as small packets of layers interlayered with phlogopite. The only area observed to have a significant amount of chlorite is the area shown in Fig. 5, in which a packet of 30 chlorite layers is separated from a packet of phlogopite layers by an $800 \AA$ thick transition zone of mixed phlogopite and chlorite layers. Microcrystalline calcite also occurs in close association with this transition zone. Unfortunately, the size of the chlorite packet is smaller than that which can be resolved by energy dispersive analysis. X-ray spectra obtained for the chlorite were contaminated with spectral peaks from phlogopite and calcite and therefore no quantitative data could be obtained for the chlorite. Nevertheless, comparing the differences between spectra from the fresh phlogopite region (Fig. $7 \mathrm{a}$ ) and from the chlorite region (Fig. 7 d) gives 

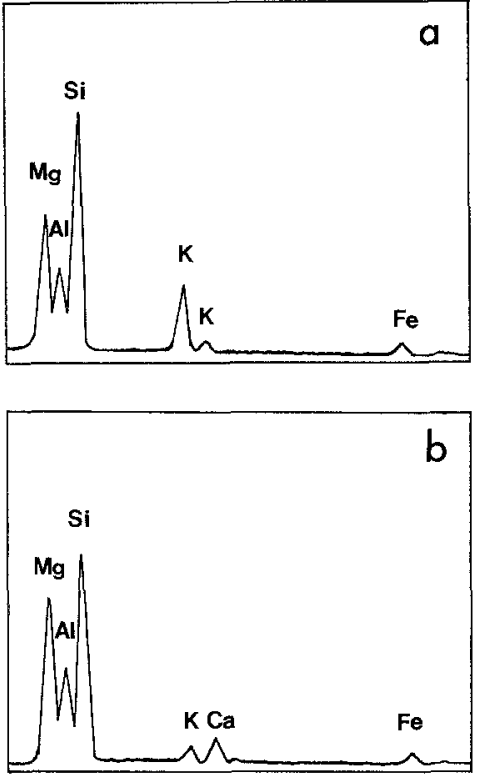

Fig. 7a+b. X-ray spectra obtained from a a fresh phlogopite region, $\mathbf{b}$ a chlorite packet with small amount of phlogopite and calcite

qualitative data on the composition of chlorite. Subtracting the relative intensities of peaks from the contaminant phlogopite and the $\mathrm{Ca}$ peak from calcite suggests that chlorite consists mainly of $\mathrm{Mg}, \mathrm{Al}, \mathrm{Si}$ and a small amount of $\mathrm{Fe}$. The intensity ratio of $\mathrm{Al}$ to $\mathrm{Si}$ corresponds to a molar ratio of approximately $2: 3$. As very little Fe is present, this suggests that the chlorite composition approximates that of clinochlore $\left(\mathrm{Mg}_{5} \mathrm{Al}_{2} \mathrm{Si}_{3} \mathrm{O}_{10}(\mathrm{OH})_{8}\right)$. Although this is qualitative at best, it does place limits on the chlorite composition, and therefore allows estimates to be made of the changes in composition attendant to the replacement.

\section{Discussion}

The observed interlayering relations between phlogopite and chlorite appear to be the result of a replacement reaction. Phlogopite and chlorite both contain a talc-like layer as the major structural unit but they differ in that where phlogopite has a $\mathrm{K}^{+}$ion as an interlayer component, chlorite contains a brucite-like layer. This difference causes $\mathrm{d}(001)$ to be approximately $10 \AA$ in phlogopite and $14 \AA$ in chlorite. In view of the analogies in structure of the talclike unit, transformations may only involve changes in the interlayer units. For example, Olives and Amouric (1984) observed a brucite-like layer as continuous with an interlayer unit of biotite and suggested that the chlorite formed by insertion of a brucite-like layer in the interlayer region of the mica structure, from which $\mathrm{K}^{+}$is removed. We have observed a relation showing one phlogopite layer as continuous with one chlorite layer (Fig. 6c), which may have formed by this insertion mechanism. In addition, Veblen and Ferry (1983) observed another type of transformation, in which two mica layers tranform into a single chlorite layer. They proposed that the transformation takes place primarily by the replacement of a TOT mica unit by a brucite-like layer. We have also observed this kind of transformation where two phlogopite layers terminated against a single chlorite layer (Fig. 6b). However, high resolution

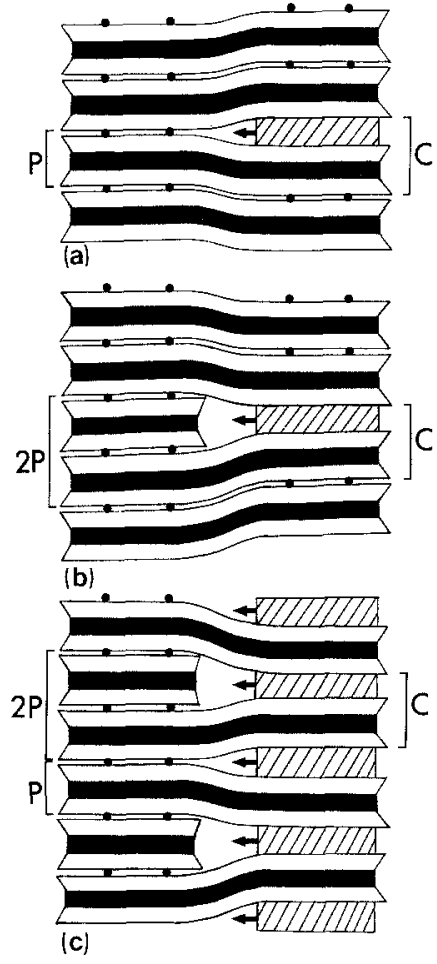

Fig. 8a-c. Possible structural relations of phlogopite (P) and chlorite (C) for a a 1:1 reaction, $\mathbf{b}$ a $2: 1$ reaction, $\mathbf{c}$ combination of $1: 1$ and $2: 1$ reactions

structural images were not obtained and we cannot therefore resolve the brucite-like layer in chlorite and the octahedral sheet in the TOT mica unit so as to trace their spacial relations across the interface. The reaction mechanism for this kind of transformation involves more than the simple removal of $\mathrm{K}^{+}$or tetrahedral sheets of one mica layer. Mass balance relations require significant concomitant cation diffusion and interchange, with implications for some structural reconstruction. For convenience, we refer here to the former transformation as a $1: 1$ reaction (one mica to one chlorite) and the latter transformation as a $2: 1$ reaction (two micas to one chlorite). Their possible structural relations are schematically shown in Fig. $8 \mathrm{a}$ and $\mathrm{b}$ respectively (modified after Veblen and Ferry).

Both the $1: 1$ and $2: 1$ reactions are accompanied by a significant change in volume. Because the principal topological features of the transformation between phyllosilicates are related to interlayer changes (Olives et al. 1983), the resultant changes in volume are approximately equal to the change in $\mathrm{d}(001)$. In the case of the $1: 1$ reaction, the transformation from phlogopite to chlorite results in a $40 \%$ expansion in volume whereas in the case of the $2: 1$ reaction, the volume decreases approximately $30 \%$. In both instances, this is a large volume change. As we observed many layers in the process of transformation, it is clear that the transition occurs by progression along an individual layer. At the site of transition there must therefore be significant strain due to the volume change. As shown in Fig. 6b, where the transformation involves only a single layer, dramatic strain effects are apparent in nearby structural layers as evidenced by strain contrast. Because the reactions tend to minimize the interfacial energy (Iijima and Zhu 1982), we propose that neither mechanism is likely 
to occur alone on a large scale. However, the volume change can be compensated to a first approximation by combining both mechanisms of replacement resulting in a minimum of strain at the reaction front. Indeed, we observed an interlayering transformation of a relatively thick packet of layers, in which 14 phlogopite layers are seen to transform to 10 chlorite layers (Fig. 6d). As the thickness of both packets is approximately $140 \AA$, there is no apparent volume change. The lack of significant strain contrast associated with the interface further supports this conclusion. Possible structure relations for this transformation are schematically shown in Fig. 8c. If 8 of 14 phlogopite layers transform to 4 chlorite layers by the $2: 1$ reaction and the remaining 6 layers transform to 6 chlorite layers through the $1: 1$ reaction, the volume remains essentially unchanged and no strain contrast should be observed. While we have observed such a feature only once, we believe that it may be representative of the replacement process which has gone to completion in most cases and it is indeed rare that the "along-layer" transition can be detected en camera.

It is important to consider the chemical aspects of the transformation in order to give a complete picture of replacement processes. From the observed mineral assemblages, replacement may take place by the following reactions:

$$
\begin{aligned}
& \mathrm{KMg}_{3} \mathrm{AlSi}_{3} \mathrm{O}_{10}(\mathrm{OH})_{2}+\mathrm{CaAl}_{4} \mathrm{Si}_{2} \mathrm{O}_{10}(\mathrm{OH})_{2} \\
& \left.+\mathrm{SiO}_{2}+2 \mathrm{CaMg}_{2} \mathrm{CO}_{3}\right)_{2}+3 \mathrm{H}_{2} \mathrm{O} \\
= & \mathrm{Mg}_{5} \mathrm{Al}_{2} \mathrm{Si}_{3} \mathrm{O}_{10}(\mathrm{OH})_{8}+\mathrm{KAl}_{3} \mathrm{Si}_{3} \mathrm{O}_{10}(\mathrm{OH})_{2} \\
& +3 \mathrm{CaCO}_{3}+\mathrm{CO}_{2} . \\
2 & \mathrm{KMg}_{3} \mathrm{AlSi}_{3} \mathrm{O}_{10}(\mathrm{OH})_{2}+\mathrm{CaCO}_{3}+\mathrm{CO}_{2}+\mathrm{H}_{2} \mathrm{O}+2 \mathrm{H}^{+} \\
= & \mathrm{Mg}_{5} \mathrm{Al}_{2} \mathrm{Si}_{3} \mathrm{O}_{10}(\mathrm{OH})_{8}+\mathrm{CaMg}\left(\mathrm{CO}_{3}\right)_{2} \\
& +3 \mathrm{SiO}_{2}+2 \mathrm{~K}^{+} .
\end{aligned}
$$

The first reaction describes the conversion of one phlogopite to one chlorite and may account for the chemical changes of the 1:1 reaction, while the second reaction describes the conversion of two phlogopites to one chlorite and may account for those of the $2: 1$ reaction. Based on chemical arguments, Veblen and Ferry (1983) also suggested that more than one reaction mechanism operated during the replacements. On the basis of observed textural relations (Fig. 6d), we suggest that a pervasive replacement of mica by chlorite occurs through a combination of the $1: 1$ and $2: 1$ reactions. If $60 \%$ of the chlorite formed by the $1: 1$ reaction (reaction (6)) and $40 \%$ of the chlorite formed by the $2: 1$ reaction (reaction (7)), the resultant change is:

$$
\begin{aligned}
14 & \mathrm{KMg}_{3} \mathrm{AlSi}_{3} \mathrm{O}_{10}(\mathrm{OH})_{2}+6 \mathrm{CaAl}_{4} \mathrm{Si}_{2} \mathrm{O}_{10}(\mathrm{OH})_{2} \\
& \left.+8 \mathrm{CaMg}_{3} \mathrm{CO}_{3}\right)_{2}+22 \mathrm{H}_{2} \mathrm{O}+8 \mathrm{H}^{+} \\
= & 10 \mathrm{Mg}_{5} \mathrm{Al}_{2} \mathrm{Si}_{3} \mathrm{O}_{10}(\mathrm{OH})_{8}+6 \mathrm{KAl}_{3} \mathrm{Si}_{3} \mathrm{O}_{10}(\mathrm{OH})_{2} \\
& +14 \mathrm{CaCO}_{3}+6 \mathrm{SiO}_{2}+2 \mathrm{CO}_{2}+8 \mathrm{~K}^{+} .
\end{aligned}
$$

Considering only the interface where 14 phlogopite layers transform to 10 chlorite layers, the composite chemical change is:

$$
\begin{aligned}
& 14 \mathrm{KMg}_{3} \mathrm{AlSi}_{3} \mathrm{O}_{10}(\mathrm{OH})_{2} \\
& \quad+8 \mathrm{Mg}^{2+}+6 \mathrm{Al}^{3+}+28 \mathrm{H}^{+}+12 \mathrm{H}_{2} \mathrm{O} \\
& =10 \mathrm{Mg}_{5} \mathrm{Al}_{2} \mathrm{Si}_{3} \mathrm{O}_{10}(\mathrm{OH})_{8}+14 \mathrm{~K}^{+}+12 \mathrm{Si}^{4+}
\end{aligned}
$$

The formulae in these equations are those of ideal end members, but they are reasonable approximations to the actual compositions. To a first approximation, Eq. 9 reflects the principal losses and gains. The transformation from 14 phlogopite to 10 chlorite, therefore, involves a sig- nificant flux of cations and $\mathrm{H}_{2} \mathrm{O}$. Not only is the structural topology changed, but major changes in composition occur which involve both tetrahedral and octahedral sites in the talc-like layers. The topological and site occupancy changes appear to occur only at the reaction front (such as shown in Fig. 6d). Although conjectural, it seems reasonable to imagine the reaction as one which involves considerable local rupturing and reformation of bonds even in those units which are structurally unchanged after the transformation.

Because the transformation must involve considerable mass change, there must be some transport mechanism. In Fig. 6d, we observe four edge dislocations in association with the phlogopite termination as results from the $2: 1$ reaction. In addition, the edge dislocation at the termination of an inserted brucite-like layer resulting from the 1:1 reaction is implied to exist by the structure relations (see schematic drawing in Fig. $8 \mathrm{c}$ ), although we were unable to resolve it in our images. Although the actual geometry of these edge dislocations is unknown, it must be a column of several Angstroms in diameter lacking the translational periodic structure of the terminating unit. We therefore propose that it is dislocations which serve as the pathway for the fluid flow and transport of the ions which are gained or lost in the reaction. Veblen and Buseck (1980) also suggested that edge dislocations may act very much like continuous voids in structures such as zeolites. This requires that the dislocations (layer terminations) are not a passive result of the transformation, but an essential active element. While speculative, the reactions provide a framework for both the structural and chemical changes attendent to the replacement process, and provide evidence for the diffusion pathways which must exist for such transformations.

Acknowledgment. We thank Mr. Richard Bostwick for providing us with the specimen. We are indebted to Dr. P.J. Dunn for calling our attention to this very unusual occurrence of margarite. We thank Drs. Larry F. Allard and Wilbur C. Bigelow for their efforts in maintaining the instruments. This work was supported by NSF grant EAR-8107529 to Donald R. Peacor.

\section{References}

Anovitz LM, Essene EJ (1984) Phase equilibria in the system $\mathrm{CaCO}_{3}-\mathrm{MgCO}_{3}-\mathrm{FeCO}_{3}$. J Meta $\mathrm{Geol}$ (in submission)

Bailey SW (1975) Cation ordering and pseudosymmetry in layer silicates. Am Mineral 60:175-187

Baker DR, Buddington AF (1970) Geology and magnetite deposits of Franklin quadrangle and part of the Hamburg quadrangle, New Jersey. US Geol Survey Prof Paper 638

Berner RA, Holdren GR, Jr (1977) Mechanism of feldspar weathering: Some observational evidence. Geology 5:369-372

Burnham CW, Holloway JR, Davis NF (1969) Thermodynamic properties of water to $1,000^{\circ} \mathrm{C}$ and 10,000 bars. Geol Soc Am Spec Pap 132

Cressey BA, Wittaker EJW, Hutchinson JL (1982) Morphology and alteration of asbestiform grunerite and anthophyllite. Mineral Mag 46:77-87

Ferry JM (1979) Reaction mechanisms, physical conditions, and mass transfer during hydrothermal alteration of mica and feldspar in granitic rocks from south-central Maine, USA. Contrib Mineral Petrol 68:125-139

Goldsmith JR, Newton RC (1969) P-T-X relations in the system $\mathrm{CaCO}_{3}-\mathrm{MgCO}_{3}$. J Geol 69:45-74

Hazen RM, Burnham CW (1973) The crystal structures of onelayer phlogopite and annite. Am Mineral 58:889-900

Hoschek G (1973) Die Reaktion Phlogopit + Calcit + Quartz = Tre- 
molit + Kalifeldspat $+\mathrm{H}_{2} \mathrm{O}+\mathrm{CO}_{2}$. Contrib Mineral Petro 63:175-198

Iijima S, Zhu J (1982) Electron microscopy of a muscovite-biotite interface. Am Mineral 67:1195-1205

Isaacs D, Brown PE, Valley JW, Essene EJ, Peacor DR (1981) An analytical study of a pyroxene-amphibole intergrowth. Contrib Mineral Petrol 77:115-120

Jacobs GK, Kerrick DM (1981) Devolatilization equilibria in $\mathrm{H}_{2} \mathrm{O}-\mathrm{CO}_{2}$ and $\mathrm{H}_{2} \mathrm{O}-\mathrm{CO}_{2}-\mathrm{NaCl}$ fluids: An experimental and thermodynamic evaluation at elevated pressures and temperatures. Am Mineral 66:1135-1153

Kerrick DM, Jacobs GK (1981) A modified Redlich-Kwong equation for $\mathrm{H}_{2} \mathrm{O}, \mathrm{CO}_{2}$ and $\mathrm{H}_{2} \mathrm{O}-\mathrm{CO}_{2}$ mixtures at elevated pressures and temperatures. Am J Sci 281:735-767

Lee JH, Peacor DR (1983) Intralayer transitions in phylosilicates of Martinsburg shale. Nature 303:608-609

Olives JO, Amouric M, De Fouguet C, Baronnet A (1983) Interlayering and interlayer slip in biotite as seen by HRTEM. Am Mineral 68:754-759

Olives JO, Amouric M (1984) Biotite chloritization by interlayer brucitization as seen by HRTEM. Am Mineral 69:869-871

Nakajima Y, Ribbe PH (1980) Alteration of pyroxenes from Hokkaido, Japan, to amphibole, clays, and other biopyriboles. N Jahrb Mineral Monatsh 6:258-268

Page RH, Wenk HR (1979) Phyllosilicate alteration of plagioclase studied by transmission electron microscopy. Geology $7: 393-397$

Page RH (1980) Partial interlayers in phyllosilicates studied by transmission electron microscopy. Contrib Mineral Petrol 75:309-314

Robie RA, Hemingway BS (1984) Heat capacities and entropies of phlogopite $\left.\left(\mathrm{KMg}_{3} \mathrm{AlSi}_{3} \mathrm{O}_{10}(\mathrm{OH})\right)_{2}\right)$ and paragonite $\left(\mathrm{NaAl}_{2}\right.$ $\left.\mathrm{AlSi}_{3} \mathrm{O}_{10}(\mathrm{OH})_{2}\right)$ between 5 and $900 \mathrm{~K}$ and estimates of the enthalpies and Gibbs free energies of formation. Am Mineral 69: 858-868

Robie RA, Hemingway BS, Fisher JR (1978) Thermodynamic properties of minerals and related substances at $298.15 \mathrm{~K}$ and 1 bar (10 pascals) pressure and at higher temperatures. US Geol Survey Bull 1452
Robinson GR, Jr, Haas JL, Jr, Schafer CM, Haselton HT, Jr (1982) Thermodynamic and thermophysical properties of selected phases in the $\mathrm{MgO}-\mathrm{SiO}_{2}-\mathrm{H}_{2} \mathrm{O}-\mathrm{CO}_{2}, \mathrm{CaO}-\mathrm{Al}_{2} \mathrm{O}_{3}-\mathrm{SiO}_{2}-$ $\mathrm{H}_{2} \mathrm{O}-\mathrm{CO}_{2}$, and $\mathrm{Fe}-\mathrm{FeO}-\mathrm{Fe}_{2} \mathrm{O}_{3}-\mathrm{SiO}_{2}$ chemical systems, with special emphasis on the properties of basalts and their mineral components. US Geol Surv Open-File Rept 83:79

Rucklidge JC, Gasparrini EL (1969) Specifications of a complete program for processing electron microprobe data: EMPADR VII. Dept Geology, University of Toronto

Shmulovich KI, Shmonov VM (1975) Fugacity coefficients for $\mathrm{CO}_{2}$ from 1.0132 to 10,000 bar and $450-1,300 \mathrm{~K}$. Geochem Int'1 12(2): 202-207

Slaughter J, Wall VJ, Kerrick DM (1976) APL computer programs for thermodynamic calculations of $\mathrm{P}-\mathrm{T}-\mathrm{X}_{\mathrm{CO}_{2}}$ space. Contrib Mineral Petrol 54:157-171

Storre B, Nitsch KH (1974) Zur Stabilität von Margarit im System $\mathrm{CaO}-\mathrm{Al}_{2} \mathrm{O}_{3}-\mathrm{SiO}_{2}-\mathrm{H}_{2} \mathrm{O}$. Contrib Mineral Petrol 43:1-24

Stull DR and Prophet H (1971) JANAF - Thermochemical Tables $\left(2^{\text {nd }}\right.$ ed.). US National Bureau of Standards 37

Takéuchi Y (1965) Structures of brittle micas. Clays Clay Minerals 13:1-25

Valley JW, Petersen EU, Essene EJ, Bowman JR (1982) Fluorphlogopite and fluortremolite in Adirondack marbles and calculated C-O-H-F fluid compositions. Am Mineral 67:545-557

Veblen DR (1983) Microstructures and mixed layering in intergrown wonesite, chlorite, talc, biotite and kaolinite. Am Mineral $68: 566-581$

Veblen DR, Buseck PR (1980) Microstructures and reaction mechanisms in biopyriboles. Am Mineral 65:599-623

Veblen DR, Buseck PR (1981) Hydrous pyriboles and sheet silicates in pyroxenes and uralites: intergrowth microstructures and reaction mechanisms. Am Mineral 66:1107-1134

Veblen DR, Ferry JM (1983) A TEM study of the biotite-chlorite reaction and comparison with petrologic observations. Am Mineral 68:1160-1168

Accepted September 24, 1984 